\title{
The Analysis of French PME/PMI's Market Opportunities in China
}

\author{
Wu Hui \\ School of Foreign Languages, Wuhan Textile University, Wuhan, Hubei, China
}

KEY WORDS: French; PME/PMI; China market; Opportunity

ABSTRACT. This article aimed to analyze a practical issue. In considering the current world economic environment and international business development, the focus of the paper has been put on helping French small and medium sized companies to find their business opportunities in China.

\section{FRENCH PME/PMIS’ PROSPECT IN CHINA MARKET}

The past French PME/PMIs' activities build the foundation for their further development in China market. According to CGPME, the general confederation of French small and medium sized enterprises, that in recent years most of the business delegation groups visiting China were formed by the owners of small and medium size companies, which are different from that of years ago. In the year of 2003, there are greater than 2000 French small company owners have visited China. Shanghai currently has the most French enterprises in China. Among around 250 French enterprises' operations in Shanghai, 70 percent are small and medium enterprises.

\subsection{Growing Chinese market is waiting for French PME/PMIs}

Proceeding from 2001, the world economy turns into a recession period. Most of the developed countries have experienced a low annual economic growth rate in recent years. However, the import and export of China experienced a steady and high growth.

The figure below from Le Monde shows the GDP growth of China in the past years. The up warding growth trend is an irresistible temptation to all businessmen.
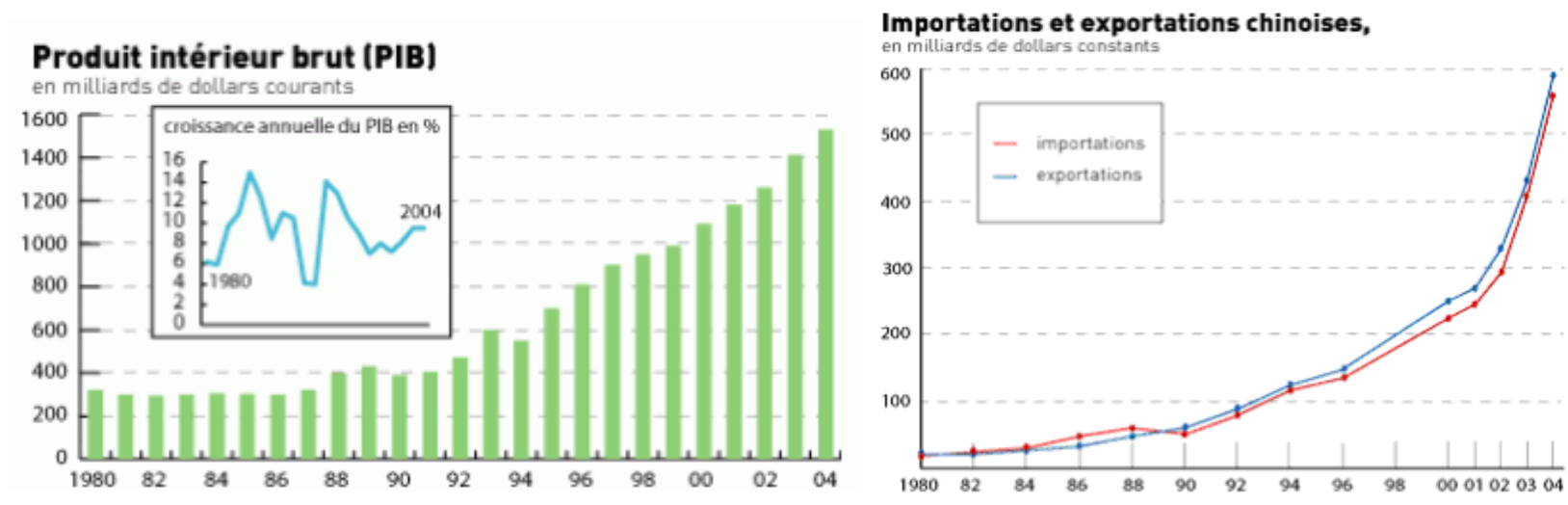

Figure 1. China GDP growth in the past years

Figure 2. Import and Export in China

The import/export record goes parallel with the GDP growth of China. Especially starting from the end of 2001 when China has acceded to the World Trade Organization, the international trade activities of China step into a new era. The import/export trade goes straight upwards. However, 
among these activities, the transaction between France and China is relatively small. There are still a lot of opportunities opening to the French PME/PMIs.

\subsection{Find your market niche in China}

Generally speaking, for French small and medium sized companies, there are three ways in looking for business opportunities in China. The first way is tantamount to refer to specialized consulting companies or intermediate companies. These companies either have plenty of experience in handling business relationship with foreign countries or have considerable business or partnership network in China. They can serve to set up a bridge between the two sides.

Meanwhile, they can also provide assistance and advice in doing business in China. The second way is to get well with the government. The government plays a very special and quite important role in the economic circle in China. Thus, government must be taken into account. The chamber of Commerce and Industry of Paris (CCIP) has established its Franco-china committee in 1997. This committee dedicated itself to providing business information for the French small and medium sized companies concerning China. They also organize forums, business visits and exhibitions to bring French PME/PMI owners to China. In 1997 and 2001, the French international technology and trade board successfully organized high-tech fare of France in Shanghai and Beijing.

Among those French companies who had participated in the high-tech fair $(150+)$, there are more than 70 percent are small and medium sized enterprises. The third way is to make good use of cyber tools. The function of which is self-evident. The Internet technology has completely changed the business world. People can easily reach information from all over the world at very low cost. In early days, only big companies who can afford to set up the network can enjoy the convenience of collecting information efficiently, so they can dominate the business opportunities. However, the popular Internet makes the information transparent. And it's known to all the business entity.

\section{CHINA'S ABSORPTION OF FRENCH INVESTMENT}

Since the reform and opening up, the rapid development of China's national economic trends for decades to promote sustained, rapid and healthy growth of the show, attracted the attention of people around the world. This article aims to analyze the basic way China attracts foreign investment and policies, prompting foreign investors to understand China's trade policy, to provide a clear idea of China attracts investment, to promote bilateral trade to maximize and achieve more bilateral trade exchanges and cooperation.

\subsection{The basic means of China's absorption of foreign investments}

Foreign investments are basically divided into direct investment and other means of investment. The direct investment, which is widely adopted, includes Sino-foreign joint ventures, joint exploitation and exclusively foreign-owned enterprises, foreign-funded share-holding companies and joint development. The other means of investment includes compensation trade and processing and assembling.

\section{a. Sino-foreign joint ventures}

Sino-foreign joint ventures are also known as share-holding corporations. They are formed in China with joint capitals by foreign companies, enterprises, other economic organizations and 
individuals with Chinese companies, enterprises, other economic organizations and individuals. The main feature is that the communal parties invest and operate together, take risk according to the ratio of their capitals and take responsibility of losses and profits.

\section{b. Cooperative businesses}

Cooperative business is also known as contractual cooperation businesses. They are established in China with joint capitals or terms of cooperation by foreign companies, enterprises, other economic organizations and individuals with Chinese companies, enterprises, other economic organizations and individuals. The rights and obligations of different parties are embedded in the contract. To establish a cooperative business, the foreign party, generally speaking, supplies all or most of the capital while Chinese party supplies land, factory buildings, and use facilities, and also some supply a certain amount of capital.

\section{c. Exclusively foreign-owned enterprises}

Exclusively foreign-owned enterprises, which are totally invested by foreign party in China by foreign companies, enterprises, other economic organizations and individuals in accordance with the laws of China. According to the law of foreign-funded enterprises, the establishment of foreign enterprises should benefit the development of our national economy and agree with at least one of the following criteria: the enterprises must adopt international advanced technology and facility; all or most of the products must be export-oriented. Foreign funded enterprises often take the form of limited liability.

\section{d. Foreign-funded share-holding companies}

Foreign-funded share-holding companies, foreign companies, enterprises, other economic organizations and individuals can form foreign funded share-holding companies in China with Chinese companies, enterprises, and other economic organizations. The total capital of the share-holding company is formed by equal shares, sharehol ders will take due responsibilities for the company according to shares purchased; company will take responsibilities for all its debts through all its assets and the Chinese and foreign shareholders will hold the shares of the company. Among them, the shares purchased and held by foreign investors is accountable for more than $25 \%$ of the total registered capital of the company.

\section{2. China's policy direction of absorption of French investment}

Measures should be taken to further improve the soft environment for French investment, explore actively new methods for absorbing French capital, put emphasis on absorbing advanced technologies, modern management and special talents, and actively absorb French capital to invest in industries of new and advanced technologies, encourage multinational to set up district headquarters, research and procurement centers; speed up the development of supporting industries and push on the service trade field to open up to French step by step.

a. Improvement of political and environment for foreign investment.

Maintain and improve an open and fair market environment. Energetically improve the political and legal environment for foreign investment, and to enhance legal administration level. We will further simplify the examination and approval procedures for foreign investment and adopt a standardized examination and approval system; reinforce our sense of legality, try to be open, just and 
transparent, and establish an incorruptible, industrious, pragmatic and effective government, creating a good administrative environment for foreign investment.

\section{b. Further open the field of service industry}

In accordance with China's self-development and commitment to the WTO, we will open this field vigorously and steadily and systematically, perfect rules and regulations for the service industry and formulate a united and standard system for accession into the market of foreign investment service. We will encourage the import of modern service concepts and advanced management experiences, technologies and modes of modern market operation, improve the structure of the service industry in China.

c. Encourage French businessmen to invest in the new high-tech industry, the basic industry, and supporting industry.

Encourage French businessmen to invest in the new high-tech industry, the basic industry, and supporting industry. The ability of technology innovation and sustainable development directly reflects the competitiveness advantages of a country. We will continue to encourage French investors to introduce, develop and innovate technology and to invest in technology-intensive project, and projects with advanced technology and to guide in enterprise registered capital proportion limitation and funding condition. The relevant stipulations of setting pioneering investment enterprise should also be consummated in order to facilitate the conditions of setting and developing high-tech corporations.

\section{CONCLUSION}

There are different ways of tapping into Chinese market. Broad choices would be direct and indirect export, licensing, joint ventures, and direct investment. Obvious the last two ways involve larger amount of commitment, control and of course profit potential.

Such outstanding regional disparity of FDI inflows is largely attributable to both the geographical advantage of the coastal provinces and preferential policies implemented in favor of these areas, though in general the low level of labor costs and the potential of the Chinese market also motivate the inflows of FDI in China. In the early 1980s, four Special Economic Zones (SEZs) were established in two coastal provinces, Guangdong and Fujian, neighbors of Hong Kong, Macao, and Taiwan, to attract the overseas Chinese investors. More recently, the gap in terms of FDI inflows between the coastal and interior regions shows some diminishing tendency as the Chinese government encourages FDI to flow into the interior regions and as the labor costs in the coastal regions have gradually grown.

\section{REFERENCES}

1. Grier Peter (1997), Exports: Rocket Fuel of U.S. Economy Selling Sandpaper's 'Sticks' to India, Christian Science Monitor, October 1, 1997, p1.

2. Laurent Belsie (1996), Small Items from Small Towns Are now Big part of U.S. Exports, Christian Science Monitor, November 13,1996, p1.

3. Bob de Wit and Ron Meyer (2002), Strategy Process, Content, Context, An International Perspective, 3rd Ed., London: Thomson, pp49-101. 
4. Tim Ambler and Chris Styles (2000), The Silk Road to International Marketing - Profit and Passion in Global Business, London: Prentice Hall, pp17-34.

5. Richard D. Lewis (1997), When Cultures Collide, London: Nicholas Berkley Publishing, pp20-24.

6. Jeffre A. Timmons and Stephen Spinelli (2004), New Venture Creation: Entrepreneurship for The 21st Century, Singapore: Mc.Graw Hill, pp15-16, pp121-125.

7. Phillp Kotler (2003), Marketing Management 11th ED.: Prentice-Hall pp383-410. 